\title{
Effects of Aqueous Extract of Aegle marmelos Root on Chronic Inflammation in Rats
}

\author{
Aktar $\mathrm{MT}^{1}$, Khan $\mathbf{I}^{2}$, Sharmin $\mathrm{ZR}^{3}$, Rahman $\mathrm{MR}^{4}$, Hoque $\mathrm{MM}^{5}$, Khanam $\mathrm{M}^{6}$, \\ Mosaddek ASM ${ }^{7}$ \\ ${ }^{1 .}$ Assistant Professor, Department of Pharmacology, \\ Shaheed Tazuddin Ahmed Medical College, Gazipur, Bangladesh \\ 2. Prof and Head, Department of Pharmacology, Dhaka Medical College, Bangladesh \\ ${ }^{3 .}$ Assistant Professor, Department of Pharmacology, Uttara Adhunik Medical College, Bangladesh \\ 4. Assistant professor, Department of Pharmacology, Green Life Medical College, Bangladesh \\ 5. Assistant Professor, Department of Pharmacology, Popular Medical College, Bangladesh \\ ${ }^{6 .}$ Lecturer, Department of Pharmacology, Dhaka Medical College, Bangladesh \\ ${ }^{7}$ Professor and Head, Department of Pharmacology, Uttara Adhunik Medical College, Bangladesh
}

\section{Corrosponding Author: Abu Syed Md. Mosaddek}

Professor and Head, Department of Pharmacology, Uttara Adhunik Medical College, Bangladesh

\begin{abstract}
Background: Pain and inflammation is a common complaint in most patients suffering from diseases. Non-steroidal anti-inflammatory drugs (NSAIDs) make up one of the largest groups of drugs used for pain and inflammation but causes side effects during their clinical uses. Therefore, the development of newer more potent anti-inflammatory drugs with lesser side effects is necessary.

Aegle marmelos plant has an important place in indigenous systems of medicine. In the study, effect of aqueous extract of Aegle marmelos root on chronic inflammation has been reported.

Methods: 24 Norwegian rats of either sex were selected and divided into 4 groups each comprise 6 rats. Chronic inflammation (granuloma) was induced by implanting one autoclaved cotton pellet $(50 \mathrm{mg})$ subcutaneously to one groin of each rat on 1st day. Group II, Group III were given aqueous extract of $A$. marmelos root at different doses and Group IV were given indomethacin orally for 14 days. Later on the $15^{\text {th }}$ day animals were anesthetized, the cotton pellets were removed. The dry weight of the granuloma was difference between the final and initial weights of the cotton pellets. The percentage change of granuloma weight relative to control group was taken as an index of chronic anti-inflammatory activity.
\end{abstract}

Results: The percent inhibition of granuloma formation was $8 \%, 13.72 \%$, and $36.19 \%$ as compared to the control in group II, III, IV respectively.

Conclusion: In chronic inflammation, Aegle marmelos root possess mild anti-inflammatory effect compared to that of indomethacin.

Keywords: Aegle marmelos root, chronic inflammation, indomethacin, granuloma.

\section{INTRODUCTION}

Inflammation is a normal protective response to tissue injury caused by physical trauma, noxious chemical or microbial agents. It is the body response to inactivate or destroy the invading organisms, to remove irritant and set the stage for tissue repair. It is triggered by the release of chemical mediators from injured tissue and migrating cells ${ }^{[1]}$.

Pain and inflammation is a common complaint in most patients suffering from disease conditions. Inflammation is a host defense mechanism to combat or overcome the invading pathogen or the 
foreign particles. Steroidal and Non-steroidal anti-inflammatory drugs (NSAIDs) are two main largest groups of drugs used for pain and inflammation ${ }^{[2]}$.

Prolonged uses of both steroidal and non steroidal anti-inflammatory drugs are well known to be associated with many adverse effects ${ }^{[3]}$. Hence, search for new anti-inflammatory agents that retain therapeutic efficacy and causes less adverse effects is justified.

There is a growing interest in traditionally used medicinal plants which produce a variety of compounds having therapeutic properties ${ }^{[4]}$. One such medicinal plant used since ancient time is Aegle marmelos (L.) belongs to the family Rutaceae. Medicinal properties of Aegle marmelos were well explained in Ayurveda, Indian traditional medicine ${ }^{[5]}$.

Various chemical constituents like alkaloids, coumarins and steroids have been isolated and identified from different parts of tree such as leaves, fruits, wood, root and bark. Alcoholic extracts of the roots and fruits showed hypoglycemic and antidiabetic activity ${ }^{[6]}$. With respect to clinical applications, it should be noted that the roots are astringent, bitter and febrifuge. They are useful in diarrhea, dysentery, dyspepsia, stomachalgia, cardiopalmus, seminal weakness, and vomiting, intermittent fever, swellings.

Considering the traditional uses and demonstrated potential medicinal properties of Aegle marmelos, present study was undertaken to investigate its anti-inflammatory potential in chronic inflammation in rats.

\section{METHODS AND MATERIAL}

The plant material i.e. roots of Aegle marmelos were collected from Botanical garden, Mirpur, Dhaka. The plant was authenticated by National Herbarium (access no.36528), Mirpur, Dhaka. The root of Aegle marmelos was cut into pieces, shade-dried and grounded to coarse powder. Aqueous extract was prepared in distilled water in the ratio of 1:16, soaked overnight and boiled next day until the volume reduced to $1 / 4^{\text {th }}$, cooled and drained ${ }^{[7]}$.

24 Long Evan Norwegian rats of either sex, weighing between 150-200g were kept under standard conditions of light and temperature, fed with animal pellets and allowed to drink water ad libitum.

Animals were divided into four groups each consisting of six rats. Chronic inflammation (granuloma) was induced by implanting one autoclaved cotton pellet $(50 \mathrm{mg})$ subcutaneously to one groin of each rat on 1st day. They were treated as follows for 14 days: Group I served as control that received normal saline, Group II and Group III were given aqueous extract of A. marmelos root at a dose of 50 $\mathrm{mg} / \mathrm{kg}$ and $100 \mathrm{mg} / \mathrm{kg}$ body weight respectively. Group IV were given indomethacin at a dose of 10 $\mathrm{mg} / \mathrm{kg}$ body weight orally. Later on the $15^{\text {th }}$ day animals were anesthetized, the cotton pellets were removed, cleaned of the extraneous tissue and dried in a hot air oven to a constant weight and the dry weight of pellets were determined. The dry weight of the granuloma was difference between the final and initial weights of the cotton pellets. The percentage change of granuloma weight relative to control group was taken as an index of chronic anti-inflammatory activity.

It was calculated by-

Percent inhibition $=100 \times(1-\mathrm{Wt} / \mathrm{Wc})$.

Where,

$\mathrm{Wt}=$ difference in pellet weight in drug treated group

$\mathrm{Wc}=$ difference in pellet weight in drug untreated control group

\section{RESUlTS AND DisCUSSION}

The chronic inflammation was induced by implanting one autoclaved cotton pellet weighting $50 \mathrm{mg}$ subcutaneously at the groin region of each rat. The day of implantation was counted as day 1 and on the $15^{\text {th }}$ day animals were anesthetized and cotton pellet with granulation tissue were dissected out, cleaned of the extraneous tissue and dried in a hot air oven to a constant weight and the dry weight of pellets were determined. The weights were $110.40 \pm 1.0 \mathrm{mg}, 105.58 \pm 0.36 \mathrm{mg}, 102.14 \pm 0.36 \mathrm{mg}$, $88.60 \pm 0.30 \mathrm{mg}$, for group I, II, III and IV respectively. 
In the study the mean initial weight of cotton pellets were $50.17 \pm 0.02 \mathrm{mg}$. The increment in the weight of cotton pellet in aqueous extract of Aegle marmelos root $50 \mathrm{mg} / \mathrm{kg}$, aqueous extract of Aegle marmelos root $100 \mathrm{mg} / \mathrm{kg}$ and indomethacin $10 \mathrm{mg} / \mathrm{kg}$ treated groups were $55.40 \pm 0.36 \mathrm{mg}, 51.96 \pm$ $0.56 \mathrm{mg}$ and $38.43 \pm 0.28 \mathrm{mg}$ respectively. Whereas, the increment of cotton pellet weight in control group was $60.22 \pm 1.02 \mathrm{mg}$. The percentage of inhibition of granuloma formation were $8 \%, 13.72 \%$, and $36.19 \%$ as compared to the control in aqueous extract of Aegle marmelos root $50 \mathrm{mg} / \mathrm{kg}, 100$ $\mathrm{mg} / \mathrm{kg}$ and indomethacin $10 \mathrm{mg} / \mathrm{kg}$ treated groups respectively.

The percent inhibition with aqueous extract of $A$. marmelos root (8\% and $13.72 \%$ ) was comparatively less than that of indomethacin (36.19\%).

Table I: Effects of Aegle marmelos root extract, Indomethacin on cotton pellet induced granuloma.

\begin{tabular}{|l|l|l|l|l|l|}
\hline Groups & $\begin{array}{l}\text { Number } \\
\text { of rats } \\
\text { (n) }\end{array}$ & $\begin{array}{l}\text { Initial weight of } \\
\text { cotton pellet }(\mathrm{mg}) \\
\text { (mean } \pm \text { SEM) }\end{array}$ & $\begin{array}{l}\text { Final weight of } \\
\text { cotton pellet }(\mathrm{mg}) \\
\text { (mean } \pm \text { SEM) }\end{array}$ & $\begin{array}{l}\text { Increase in weight of } \\
\text { cotton pellet (mg) } \\
\text { (mean } \pm \text { SEM) }\end{array}$ & $\begin{array}{l}\text { Inhibition of } \\
\text { granuloma } \\
\text { formation } \\
(\%)\end{array}$ \\
\hline $\begin{array}{l}\text { Group-I } \\
\text { (control) }\end{array}$ & 6 & $50.17 \pm 0.02$ & $110.40 \pm 1.0$ & $60.22 \pm 1.02$ & -- --- \\
\hline $\begin{array}{l}\text { Group-II } \\
\text { (root extract } \\
50 \mathrm{mg} / \mathrm{kg})\end{array}$ & 6 & $50.17 \pm 0.02$ & $105.58 \pm 0.36$ & $55.40 \pm 0.36^{*}$ & $8 \%$ \\
\hline $\begin{array}{l}\text { Group-III } \\
\text { (root extract } \\
100 \mathrm{mg} / \mathrm{kg})\end{array}$ & 6 & $50.17 \pm 0.02$ & $102.14 \pm 0.36$ & $51.96 \pm 0.56^{*}$ & $13.72 \%$ \\
\hline $\begin{array}{l}\text { Group-IV } \\
\text { Indomethacin } \\
10 \mathrm{mg} / \mathrm{kg} \text { ) }\end{array}$ & 6 & $50.17 \pm 0.02$ & $88.60 \pm 0.30$ & $38.43 \pm 0.28^{* *}$ & $36.19 \%$ \\
\hline
\end{tabular}

I vs. II, I vs. III, I vs. IV

$* \mathrm{P}<0.05$ in a test of significance difference from control.

$* * \mathrm{P}<0.001$ in a test of significance difference from control.

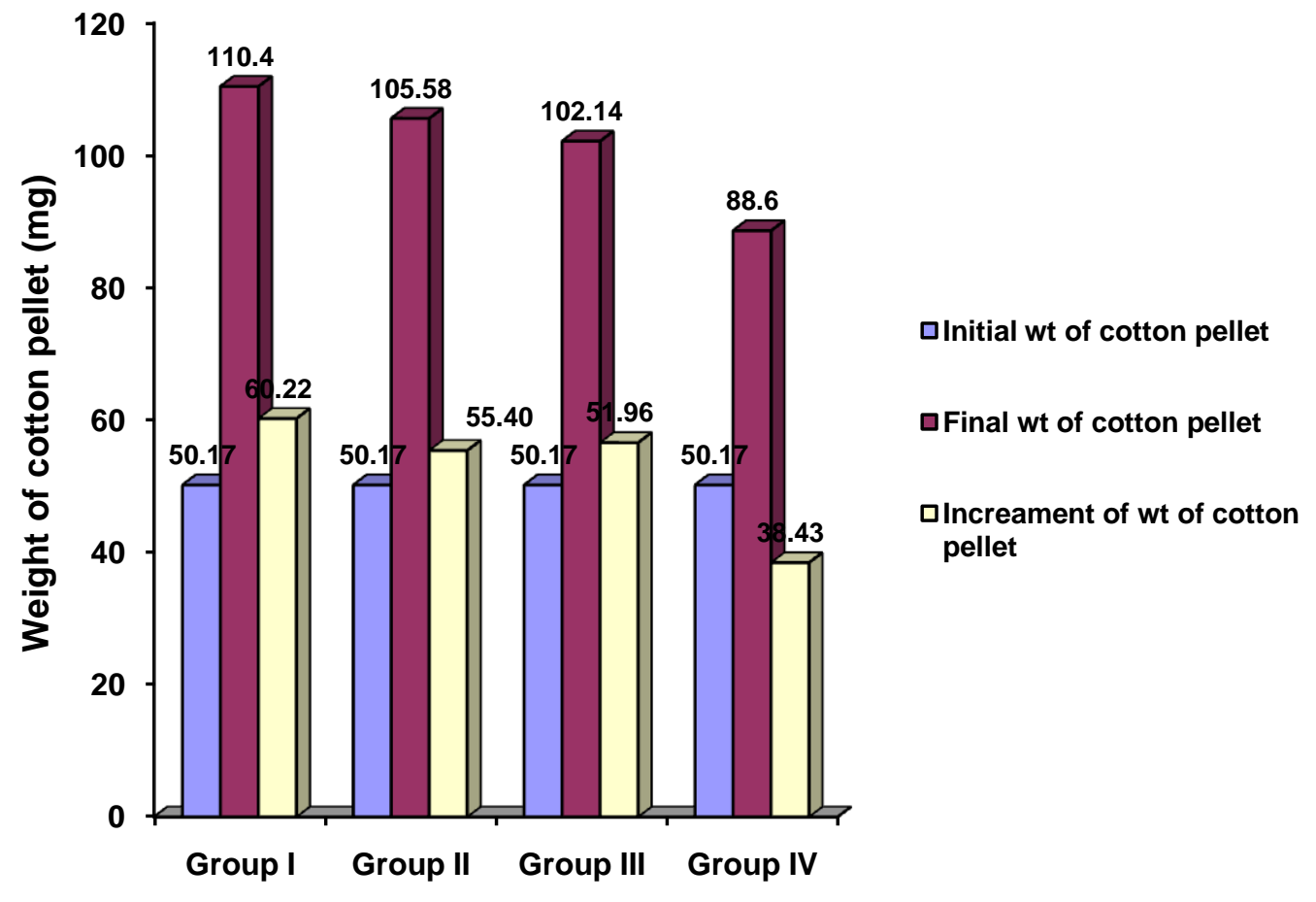

Figure-1: Bar diagram showing comparative initial, final and increments of weight of cotton pellet. 
Cotton wool granuloma is a method for testing the proliferative phase i.e granuloma formation, provoked by the subcutaneous implantation of cotton pellets. The amount of newly formed connective tissue can be measured after removal and weighing the dried pellets. Though the A. marmelos showed less chronic anti-inflammatory activity compared to indomethacin, further assessment of A. marmelos with change in the dosage solvent extracts and other chronic inflammatory models, will throw a more light on its chronic anti-inflammatory activity.

Earlier studies showed a trend of anti-inflammatory activity of aqueous extract of Aegle marmelos root in chronic model studied ${ }^{[8]}$.

In previous study, three active compounds isolated from Aegle marmelos Correa, namely aegeline, skimmianine, and marmin. These compounds potently inhibited the histamine release from rat mast cells ${ }^{[9]}$.

In anoher study, Marmin isolated from Aegle marmelos Correa could inhibit the contraction of guinea-pig tracheal smooth muscle, in particular by interfering histamine receptors, inhibiting the histamine release from mast cells ${ }^{[10]}$.

\section{Conclusions}

The present study provides an initial step in demonstrating the anti-inflammatory effect of aqueous extract of Aegle marmelos root. The obtained data support the basis for future use of Aegle marmelos root in traditional system of medicine. Thus, it could be a new agent in reducing morbidity and mortality resulting from inflammatory disease conditions.

\section{REFERENCES}

[1] Bhitre, M.J., S. Fulmali, M. Kataria, S. Anwikar and H. Kadri,. Antiinflammatory activity of the fruits of piper longum Linn. Asian J. Chemistry. 2008; 20(6):4357 -4360.

[2] Jose VM and Antony TT. Recent trends in the utilization of 'NSAIDs' in a tertiary care hospital. Indian J Pharmacol. 2003; 35:318-9.

[3] Higgs GA, Moncada S, Vane JR. Eicosanoids in inflammation. Ann Clin Res. 1984; 16:287-99.

[4] Reddy VD, Padmavathi P, Paramahamsa M, Varadacharyulu NC. Amelioration of alcoholinduced oxidative stress by Emblica officinalis (Amla) in rats. Indian J Biochem Biophys. 2010; 47:20-25.

[5] Baliga MS, Bhat HP, Pereira MM, Mathias N, Venkatesh P. Radioprotective effects of Aegle marmelos (L.) Correa (Bael): a concise review. J Altern Complement Med. 2010; 16:1109-1116.

[6] Kamalakkannan N, Rajadurai M, Prince PS. Effect of Aegle marmelos fruits on normal and streptozotocin-diabetic Wistar rats. J Med Food 2003; 6: 93-98.

[7] Pandit Sharangadharacharya. 1st shloka of 2nd chapter in Madhyama khanda. Sharangadhara samhita, 7 th Ed. Chaukamba surabharathi prakashana Varanasi, Uttar Pradesh: 2008. p. 144.

[8] Benni JM, Jayanthi MK, Suresha RN, Evaluation of the anti-inflammatory activity of Aegle marmelos root, Indian journal of Pharmacology. 2011; 43(4): 393-397.

[9] Nugroho AE, Riyanto S, Sukari MA and Maeyama K (2008). The Effects of compounds isolated from Aegle marmelos Correa on the histamine release from mast cells. The $81^{\text {st }}$ Annual Meeting of the Japanese Pharmacological Society, Yokohama, Japan, pp.189.

[10] Nugroho A.E, Anas Y, Arsito P.N, Wibowo T. J, sugeng Riyanto S. Sukari M.A effects of marmin, a compound isolated from aegle marmelos Correa, on contraction of the guinea pigisolated trachea 1 Pak. J. Pharm. Sci. 2011; 24(4): 427-433. 